\title{
Surgical Treatment of a Massive Neurofibroma of the Head and Neck in a Patient with Neurofibromatosis Type 1: A Case Report
}

\author{
Tratamiento Quirúrgico de un Neurofibroma Masivo de Cabeza y Cuello \\ en un Paciente con Neurofibromatosis Tipo 1: Reporte de un Caso
}

\author{
Haiyan Qin; Wanying Chen; Jiao Kong; Feifei Chen;Xiaoqiang Wen; Zhuonan Li \& Lianbo Zhang
}

QIN, H.; CHEN, W.; KONG, J.; CHEN, F.;WEN, X.; LI, Z. \& ZHANG, L. Surgical treatment of a massive neurofibroma of the head and neck in a patient with neurofibromatosis Type 1: A case report. Int. J. Morphol., 36(1):194-200, 2018.

SUMMARY: Neurofibromatosis type 1 (NF1) is a rare autosomal dominant neurogenetic disease with variable clinical manifestations, which are primarily manifested as neurofibromas, café-au-lait macules (CALMs) and skeletal deformities. Although generally benign, expansile neurofibromas that are characteristic of NF1 readily lead to disturbing deformities. It is often difficult to surgically extirpate a tumor that involves these important tissues or organs. We report a rare case of a patient with neurofibromatosis Type 1 . The patient presented with a congenital giant scalp neurofibroma and CALMs in the occipito-cervical region, in addition to ear and occipital deformities. We performed a challenging surgical intervention (a near-total resection) to reduce the tumor burden and rehabilitate the appearance and function of the patient while preserving the intracranial tissue structure. Here, we review this case and analyze the clinical manifestations, diagnosis and management of NF1.

KEY WORDS: Neurofibromatosis Type 1; Occipital bone defect; Ear deformity; Surgical treatment.

\section{INTRODUCTION}

Neurofibromatosis, also known as Von Recklinghausen's disease, often involves the origin of ectodermal organs, such as the nervous system, the eyes and the skin, and is a common neurocutaneous syndrome (Theos et al., 2006; Jouhilahti et al., 2011).

Neurofibromatosis includes three types: neurofibromatosis type 1 (NF1), neurofibromatosis type 2 (NF2), and schwannomatosis (NIH, 1997). NF1 is an autosomal dominant disorder affecting 1 in 2500-3500 individuals, with high penetrance. A total of $50 \%$ of patients with NF1 have a family history of the disease, or their clinical manifestations are caused by mutation of the NF1 tumor suppressor gene located on chromosome 17q11.2 (Korf, 2013; Zhu et al., 2016).

Although café-au-lait macules (CALMs) commonly appear on skin, they are an early feature of NF1. With age, other typical features begin to appear, even malignant transformation. The course of NF1 is unpredictable (Holt, 1978; DeBella et al., 2000).

Most individuals with NF1 will present with pigmentary lesions (CALMs, freckles or Lisch nodules) and neurofibromas. Moreover, some individuals suffer from skeletal abnormalities, brain tumors, peripheral nerve tumors and other symptoms (Gutmann et al., 1997; DeBella et al.). Approximately $40 \%$ of patients with neurofibromatosis type I suffer from skeletal malformations, including primary bone hypoplasia and neurofibroma erosion; however, in actual case analysis, the latter is rare (Raj et al., 2009; Arrington et al., 2013).

Cutaneous neurofibroma is the primary condition that affects skin appearance. The overgrowth of related soft tissue leads to severe deformity, and it even affects the adjacent tissues and organs (Ergün et al., 2007). When a neurofibroma grows on the scalp, it can cause a fatal hemorrhage with an abundant blood supply. The operation is extremely difficult when there is a skull defect. At present, there are few reports about NF1 presenting as a giant neurofibroma of the scalp with skull defects.

We report a case of a young female patient with NF1 that presented as a giant neurofibroma of the head and neck with ear deformity. The defective part of the occipital bone caused the transverse sinus to bulge out of the skull. 
We made full use of all types of auxiliary examinations to evaluate the risk of operation, and we created a detailed plan. The patient recovered well after the resection of the giant neurofibroma and replantation of the scalp flap with pedicel. At the same time, we analyzed and discussed the diagnosis, treatment and prognosis of the disease to provide a reference for our clinic practice.

\section{CASE PRESENTATION}

A 25-year-old female was admitted to the hospital complaining about a progressive, painless soft tissue mass of the head and neck. The swelling was a red spot that was first noticed by her parents at the age of one. The patient underwent surgery to resect the swelling 13 years ago. She had no neurological deficits and no signs or family history of NF1.
The soft tissue mass located in the left occipito-cervical region measured $27 \mathrm{~cm} \times 22 \mathrm{~cm} \times 6 \mathrm{~cm}$ and resembled a giant soft pouch. It involved the auris sinistra, which presented with a sagging deformity (Fig. 1). The external auditory canal was blocked by tumor tissue. There were many gray-brown pigment spots in the lesion area. The two largest integrated spots were located on the top of the head and behind the auris sinistra; they measured approximately $6.5 \mathrm{~cm} \times 2.7 \mathrm{~cm}$ and $12 \mathrm{~cm} \mathrm{x} 4 \mathrm{~cm}$, respectively (Fig. 2). There were no cutaneous pigmentary lesions in other parts of the body.

Auxiliary check. Color Doppler flow imaging (CDFI) showed that a giant irregular soft tissue mass was located in the occipito-cervical region on the left, with no obvious border. The ultrasonic signal of the subcutaneous soft tissue was extremely disordered. Many blood flow signals and the arterial spectrum could be measured. The sinusoids and liquid dark area measured $2.5 \mathrm{~cm} \mathrm{x} 0.95 \mathrm{~cm}$

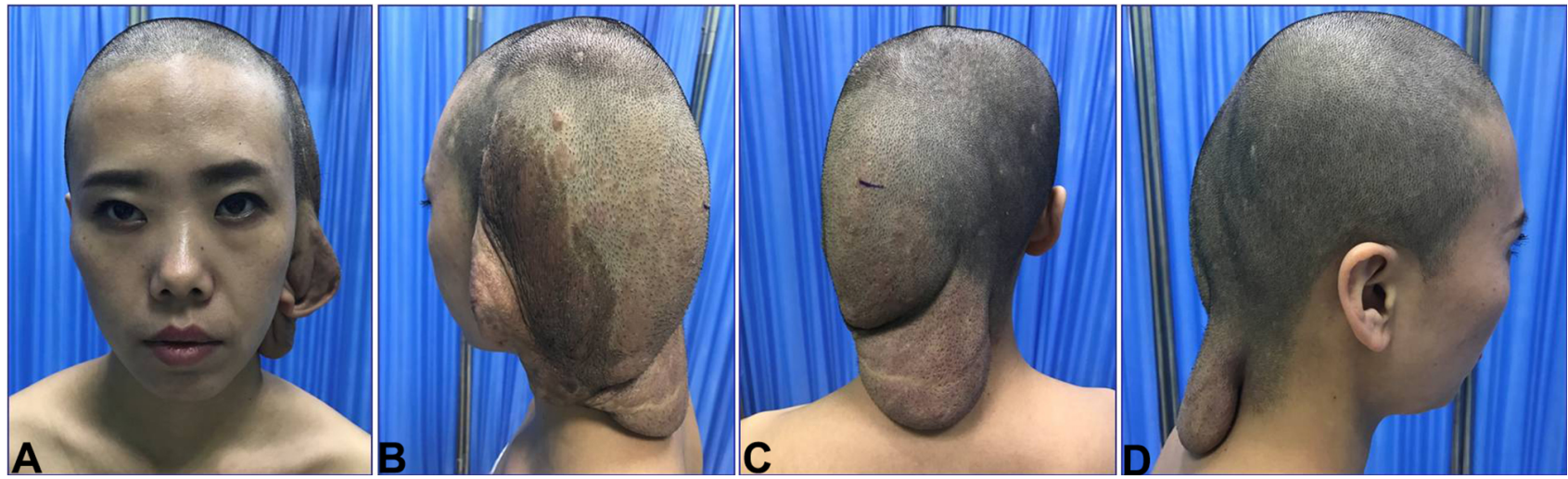

Fig. 1 A 25-year-old woman presented with a giant neurofibroma in the left scalp. Preoperative imaging: frontal, oblique, posterior and lateral views $(a, b, c, d)$.

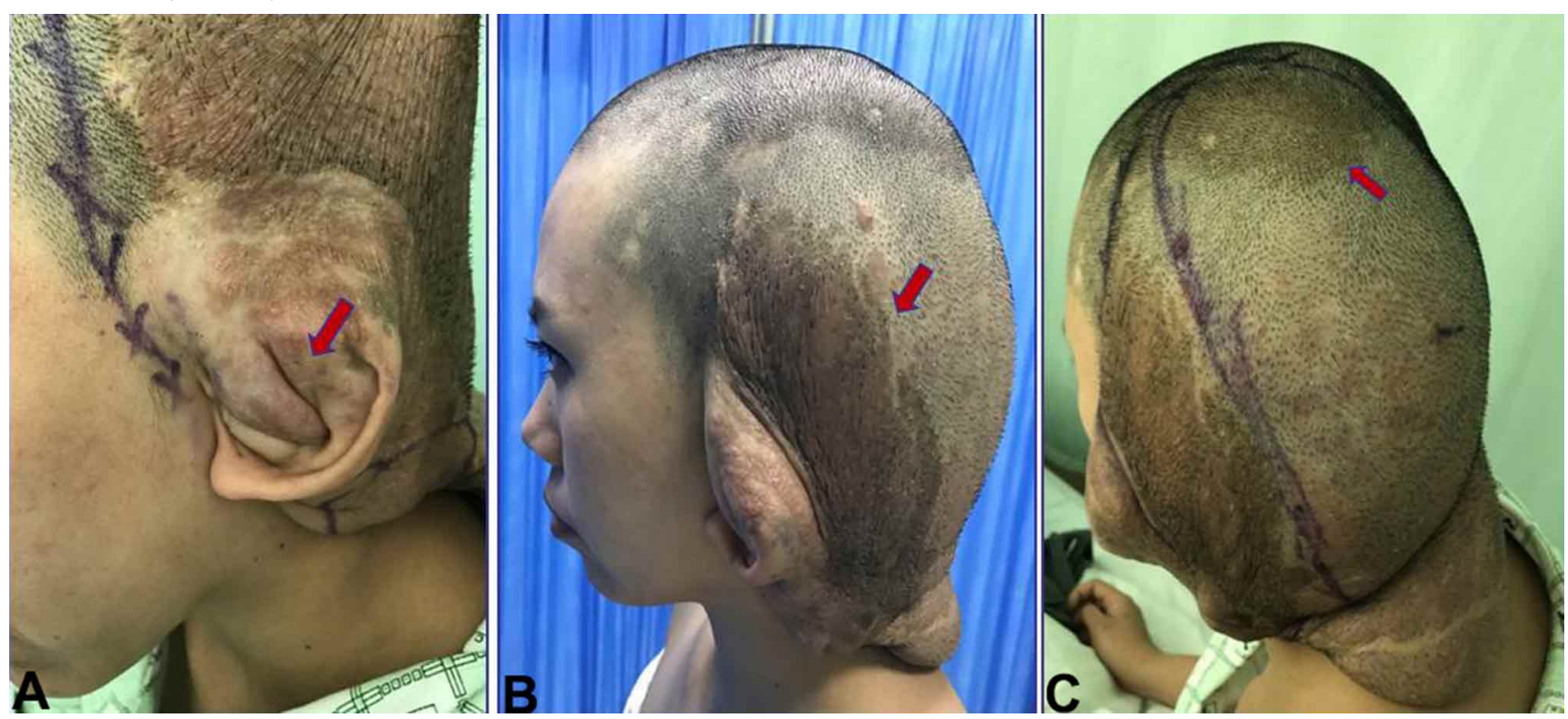

Fig. 2 A) The tumor, which involved the auris sinistra and the external auditory canal, is blocked by tumor tissue (arrow); B, C) multiple, well-defined, irregular brownish lesions typical of café-au-lait spots; large fusion spots (arrow). 
and $2.1 \mathrm{~cm} \times 0.9 \mathrm{~cm}$, respectively (Fig. 3).

Magnetic resonance imaging (MRI) demonstrated that these signals in the soft tissue mass were uneven, and the brain parenchymal signal was uniform. The tumor did not invade the brain (Fig. 4).
According to CT angiography, the tumor was supplied by the bilateral external carotid artery and its branches. The left external carotid artery and its branches ran through the tumor (Fig. 5). Part of the left transverse sinus was bulging outward. There was no obvious boundary between the transverse sinus and the tumor (Fig. 8-b).
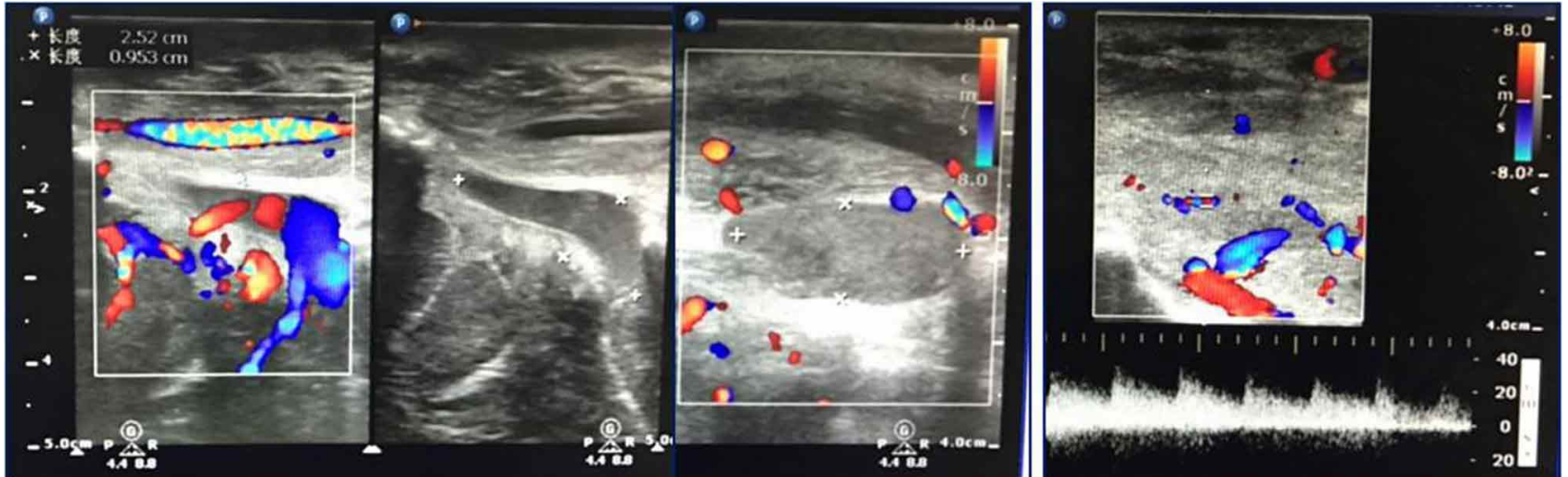

Fig. 3 Color Doppler flow imaging (CDFI): A) Ultrasound showed abundant blood flow signal in the lesions. There was echo of the sinusoids and liquid dark area; B) the arterial spectrum can be measured in the lesions.
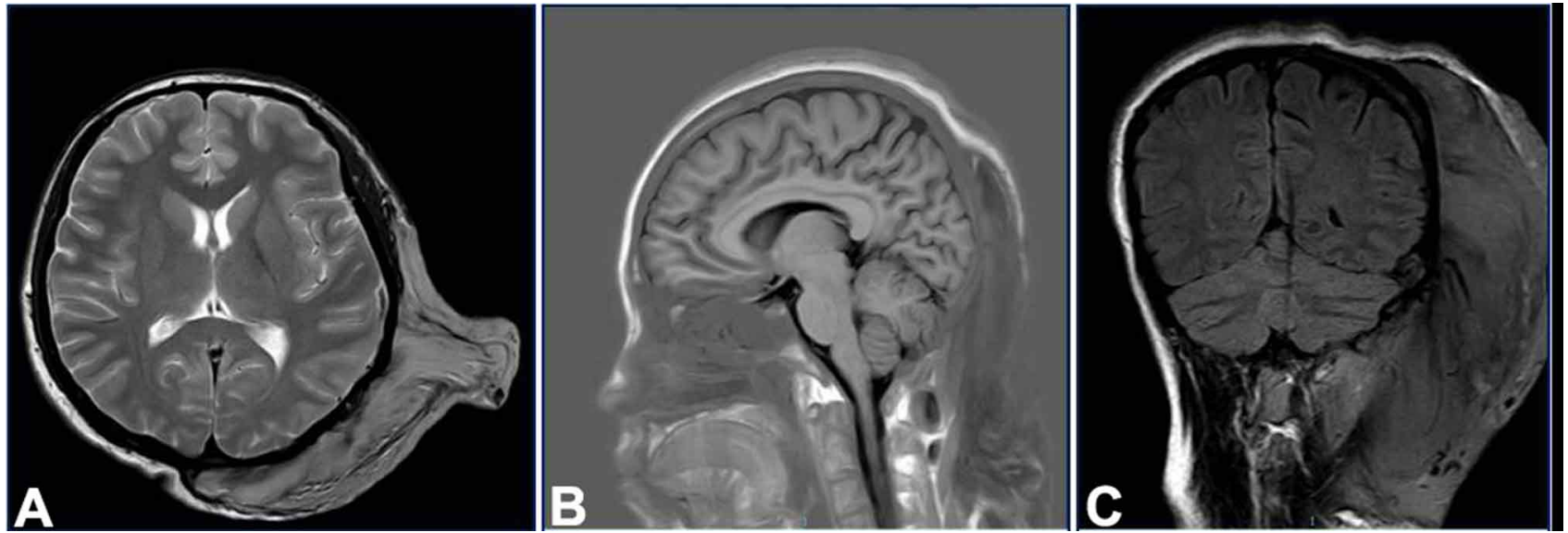

Fig. 4. Craniofacial MRI demonstrated that there were no intracranial space-occupying lesions, and the signal of the cerebral essence was uniform (a: eT2W_TSE Axial view; b: eT1W_IR midsagittal view; c: eFLAIR_LongTR coronal view).
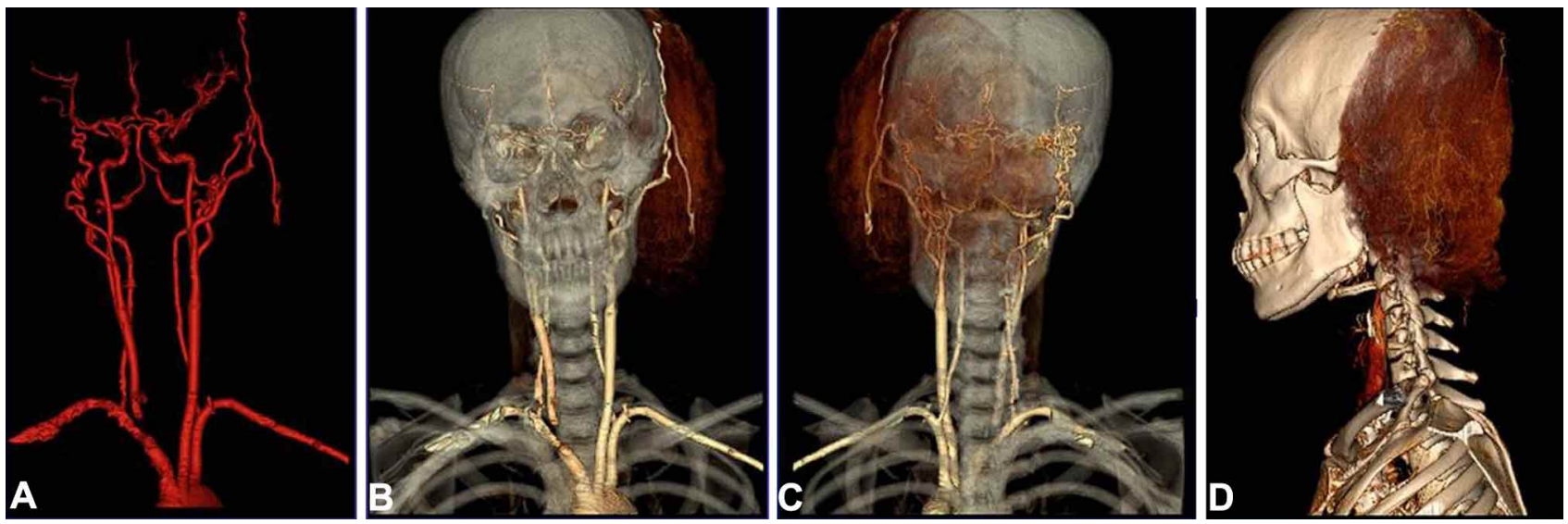

Fig. 5. Computed tomography angiography (CTA): Three-dimensional reconstruction of the carotid artery and three-dimensional integrated reconstruction revealed that the tumor was supplied by the bilateral external carotid artery and its branches. The left external carotid artery and its branches ran through the mass. 
Three-dimensional reconstructions of the bony tissue and a CT scan demonstrated that the patient had a partial occipital defect (Fig. 6).
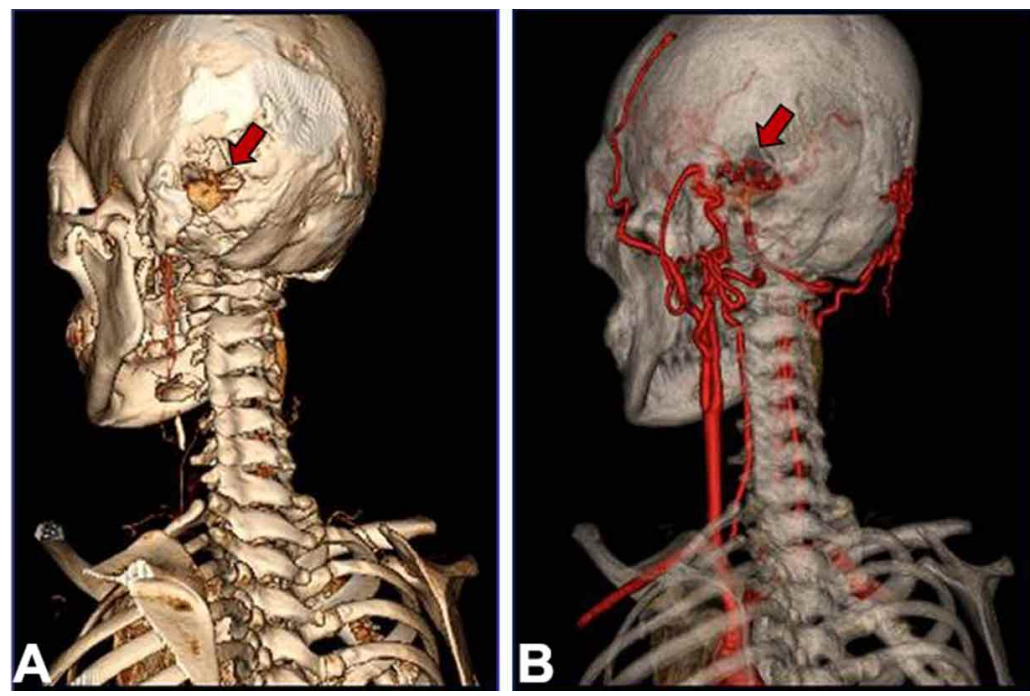

Digital subtraction angiography (DSA) of the bilateral external carotid artery showed that the tumor was supplied by the bilateral occipital artery (Fig. 7-a, b). DSA of the left

Fig. 6. Three-dimensional reconstruction of bony tissue and blood vessels (a, b) and a CT scan (c) showed a defect in the occipital bone (arrow).

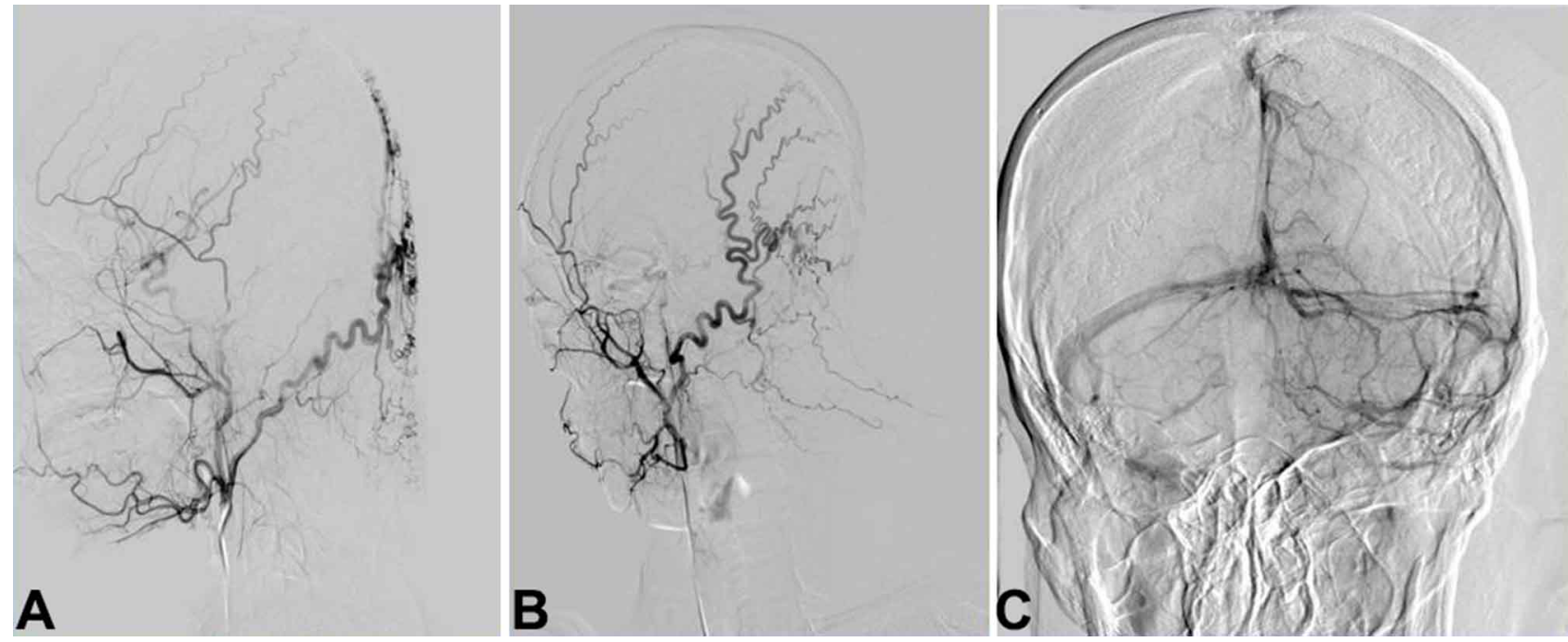

Fig. 7. DSA of the bilateral external carotid artery showed that the tumor was supplied by the bilateral occipital artery, and the right occipital artery was the main nutrient artery. a) DSA of the left external carotid artery; b) DSA of the left external carotid artery; c) DSA of the left internal carotid artery.
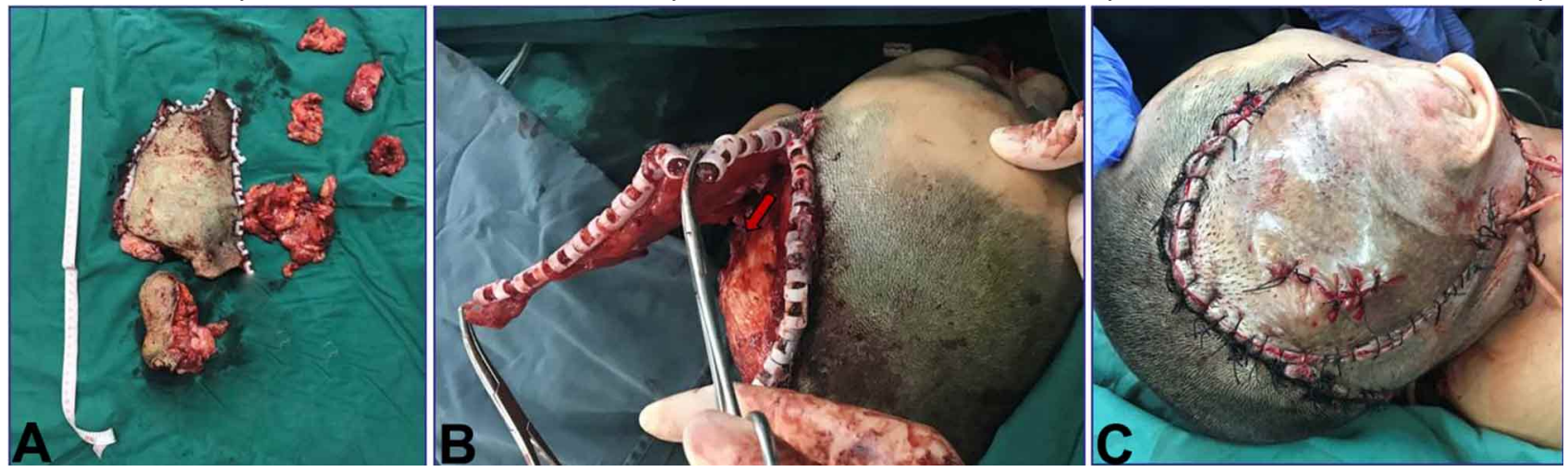

Fig. 8. Intraoperative images. A) The amount of tissue excised in a subtotal excision is depicted in the pane. B) The location of the skull defect and the bulging transverse sinus (arrow); b, C) the tumor was resected, and some scalp was retained to cover the wound, similar to a flap. 
internal carotid artery showed that blood in the sylvian vein flowed back to the transverse sinus (Fig. 7c).

Operative and postoperative course. Before the surgery, we prepared a large supply of banked blood (erythrocyte suspension $3000 \mathrm{ml}$, plasma $1000 \mathrm{ml}$ ), expanded the volume of blood, regularly used hemostatic drugs.

When general anesthesia was used, the location of the left occipital artery was confirmed by color Doppler ultrasound. A 1/100000 epinephrine saline solution was injected, and running sutures were passed around the tumor to reduce the blood supply. Subcutaneous tissue around the left occipital artery was ligated with 4-0 sutures. The normal scalp was cut to the galea aponeurotica layer on the upper edge of the tumor. The marginal scalp incision was clamped with a hemostatic clip. It was observed that the tumor tissue had invaded the periosteum. The tumor was separated from the skull downward using an electric surgical knife. Close to the defect of the occipital bone, the tumor and the subcutaneous tissue were carefully separated using tissue scissors, and the periosteum layer was retained. Subcutaneous tumor tissue from the auris sinistra was completely excised in the same manner. Redundant skin was excised, and part of skin was retained to form two flaps to cover the wound. We utilized bipolar electrocoagulation, hemostatic powder and bone wax to completely stop the wound from bleeding, and then, we sutured the wound after embedding the drainage strip. The amount of intraoperative bleeding was $2500 \mathrm{ml}$.

After the surgery, we used some drugs (Hemocoagulase Bothrops Atrox for Injection, Penglai Nuo Kang Pharmaceutical Co., Ltd, China; Dexamethasone Sodium Phosphate Injection, Shandong Xinhua Pharmaceutical Co., Ltd,China) to control the postoperative bleeding, regulate the electrolyte balance and protect the gastric mucosa.
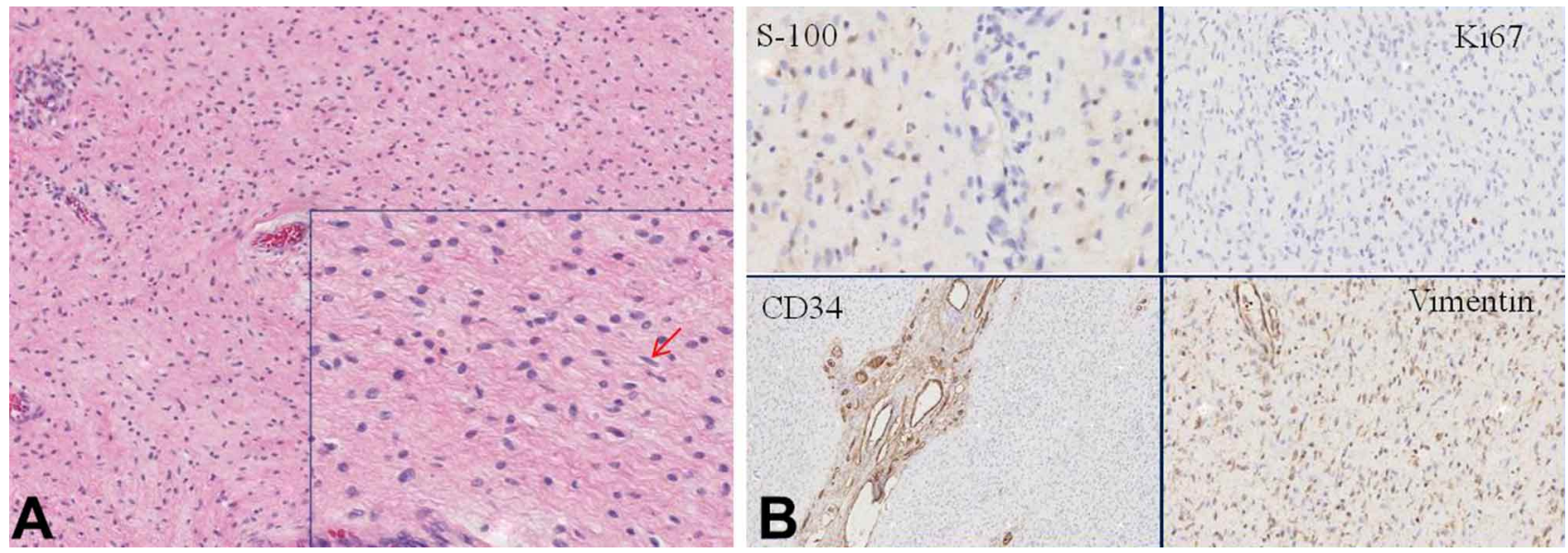

Fig. 9. Postoperative pathology studies confirmed a diagnosis of diffuse neurofibroma. A) HE staining revealed fusiform cells with elongated nuclei (arrows) and extensive invasiveness $(\times 100$; inset, $\times 200)$; B) Immunoperoxidase staining showed positive reactions: S$100(\times 200), \mathrm{CD} 34(\times 40), \mathrm{Ki} 67(<1 \%)(\times 100)$, Vimentin $(\times 100)$.
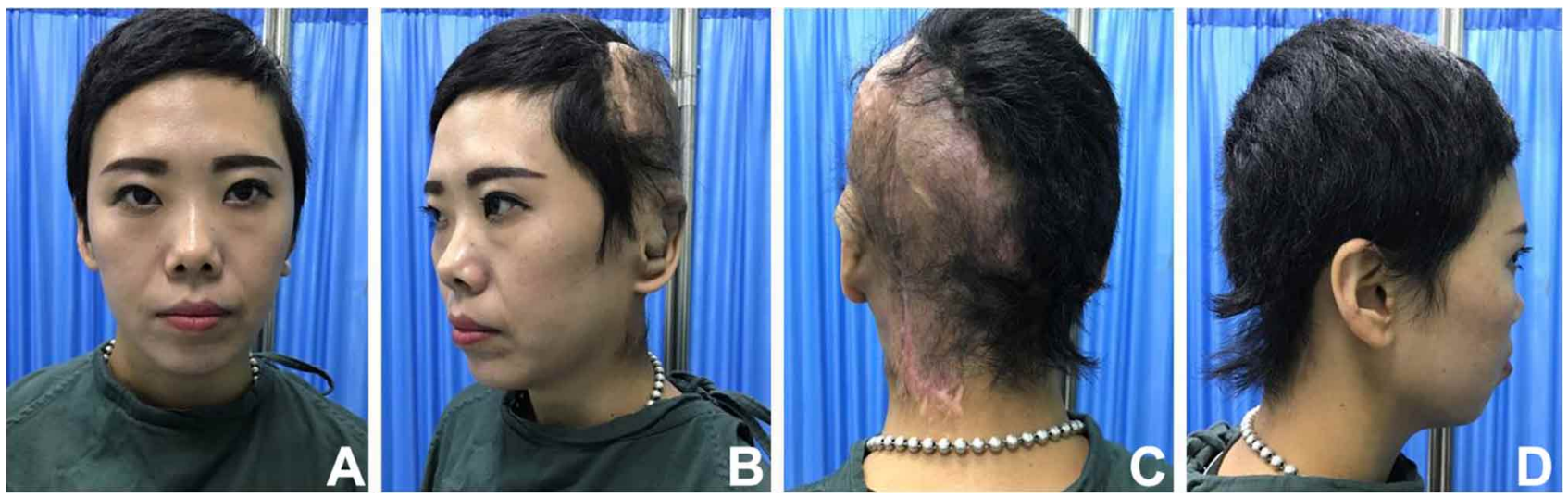

Fig. 10. Postoperative images of the patient (three months): frontal, oblique, posterior and lateral views (A, B, C, D). Note the satisfactory contour of the head and neck, as well as the appearance of the opposite normal ear for a comparison of the contour and location of the right auricle. 


\section{DISCUSSION}

NF1 is a common genetic disease with many characteristic symptoms and signs. Diagnosing the disease is usually not easy. In 1987, the NIH published diagnostic criteria for the disease, as shown in Table I. The disease can be confirmed with two or more of these features (Sehgal et al., 2013).

In this case, a patient presented with a giant dermal neurofibroma, characteristic café-au-lait macules and a characteristic occipital defect. Postoperative pathology studies confirmed a diagnosis of cutaneous diffuse neurofibroma (positive: vimentin, CD34, S-100, Ki67 [<1\%]; negative: smooth muscle actin [SMA], desmin, CD117, cytokeratin [CK], glial fibrillary acidic protein [GFAP], Bcl-2, and NeuN) (Fig. 9). Several studies have reported that approximately $10 \%$ of diffuse neurofibromas are associated with NF1 (Yoo et al., 2009; Karwacki \& Wozniak, 2012).

The clinical manifestations of the patient fulfilled two of the seven well-established criteria in Table I, and combined with the patient's history and pathological results, the disease was diagnosed as NF1.

At present, we have knowledge of the pathogenesis of NF1 (Boyd et al., 2009) and have found a variety of treatments, such as laser ablation, drugs, radiation, gene therapy and surgery (Kissil et al., 2010; Marchetti et al., 2013; Weiss et al., 2015). Although we have recently made much new progress in terms of drugs and gene therapy for NF1, surgical management is still the most effective treatment for improving patient quality of life in the case of giant neurofibromas with ill-defined borders (Latham et al., 2015). However, these lesions often have an extremely rich blood supply. Surgery is a great challenge for surgeons when neurofibromas invade important organs (Shen et al., 2016).

Auxiliary examination plays an important role in diagnosing the disease and evaluating the surgical risk (Ergün et al.; Sehgal et al., 2009).
In this case, CDFI helped us to understand the composition of the tumor and played a guiding role in the initial diagnosis of the disease; it also showed the distribution of the blood vessel and the blood sinus, which can be used to roughly estimate potential bleeding. CTA helped us to understand the arterial blood supply and distribution of the tumor as well as the anatomical relationship between the tumor and the skull. MRI helped us to understand the extent of the tumor (van Zuuren \& Posma, 2003); DSA can anticipate the blood flow within the tumor, determine whether there is an abnormal blood supply and determine if it is feasible to reduce the blood supply through embolization of vegetative arteries (Yuan et al., 2015). Considering the blood flow of the graft flap and the risk of vascular embolization, we did not consider preoperative embolization.

In this case, we chose conservative treatment (tumor subtotal resection and skin flap grafting), considering the presence of the occipital defect with transverse sinus bulging and the history of recurrence after surgery. To avoid the occurrence of intraoperative massive hemorrhage, we took the following measures: (i) prepared a large supply of allogeneic blood; (ii) performed preoperative expansion of the blood volume; (iii) used hypotensive anesthesia; (iv) placed a preliminary sutured around the tumor and stitched the tissue around the occipital artery; (v) used a scalp clip, bipolar coagulation, bone wax, hemostatic powder and adrenaline saline for intraoperative hemostasis; (vi) chose the healthy scalp on the top of the head for the surgical incision to avoid damaging the great vessels, sinus and important organizational structure, and (vii) preserved some subcutaneous tissue at the defect of the occipital bone to protect the sinus in order to avoid the occurrence of severe complications, such as massive hemorrhage and gas embolism (Raj et al.). The patient recovered well, with no complications. Her appearance has been greatly improved (Fig. 10).

Surgical management of NF1 must be individualized because of the various coexisting lesions. We must make full use of all types of auxiliary inspection techniques, combined with the patient's medical history and adequate consideration

Table I. Diagnostic criteria for neurofibromatosis type 1 (NF1). At least two of seven well-established criteria must be present

\begin{tabular}{ll}
\hline- & $\geq 6$ café-au-lait macules of $>5 \mathrm{~mm}$ in size in pre-pubertal patients, and $>15 \mathrm{~mm}$ in size in post-pubertal patients \\
- & $\geq 2$ or more dermal neuro fibromas or one plexiform neurofibroma \\
- & freckling in the axillary or inguinal regions (Crowe sign) \\
- & optic glioma \\
- & $\geq 2$ or more Lisch nodules (iris hamartomas) \\
- & orthopaedic abnormalities; and/or \\
- & a first-degree relative with NF1 based on the above criteria. \\
$\quad$ At least two of seven well-established criteria must be present
\end{tabular}


of individual needs. The key to a successful operation is to prevent bleeding, repair the large wound area, and protect the important organs and tissues (Janes et al., 2013).

The purpose of surgical management should not be to simply remove the lesion. A variety of factors should be considered before treatment. We should remove all lesions as much as possible to improve the patient's appearance, reduce the patient's psychological burden and improve patient quality of life (Zhang et al., 2012).

The applied range of medication, laser therapy and radiotherapy is currently narrow, and these effects were not significant; however, we believe that they will be more widely used in the treatment of NF1 with the continuous development of related disciplines. We also hope that with more profound and detailed understanding of the pathogenesis of NF1, a more effective treatment will be found.

FUNDING. This study was funded by the National Natural Science Foundation of China (grant no.81372068).

QIN, H.; CHEN, W.; KONG, J.; CHEN, F.;WEN, X.; LI, Z. \& ZHANG, L. Tratamiento quirúrgico de un neurofibroma masivo de cabeza y cuello en un paciente con neurofibromatosis tipo 1: Reporte de un Caso. Int. J. Morphol., 36(1):194-200, 2018

RESUMEN: La neurofibromatosis tipo 1 (NF1) es una rara enfermedad neurogenética autosómica dominante, con manifestaciones clínicas variables, que se manifiestan principalmente como neurofibromas, máculas café con leche (CALM) y deformidades esqueléticas. Generalmente los neurofibromas expansivos benignos que son característicos de NF1 conducen fácilmente a deformidades exageradas. A menudo es difícil extirpar quirúrgicamente un tumor que involucra estos tejidos u órganos importantes. Presentamos un caso raro de un paciente con neurofibromatosis tipo 1. La paciente presentó un neurofibroma congénito gigante del cuero cabelludo y CALM en la región occipitocervical, además de deformidades del oido y región occipital. Realizamos una intervención quirúrgica desafiante (una resección casi total) para reducir la carga tumoral y rehabilitar la apariencia y función de la paciente mientras se preservó la estructura del tejido intracraneal. Aquí, revisamos este caso y analizamos las manifestaciones clínicas, el diagnóstico y el tratamiento de NF1.

PALABRAS CLAVE: Neurofibromatosis tipo 1; Defecto óseo occipital; Deformidad del oído; Quirúrgico.

\section{REFERENCES}

Arrington, D. K.; Danehy, A. R.; Peleggi, A.; Proctor, M. R.; Irons, M. B. \& Ullrich, N. J. Calvarial defects and skeletal dysplasia in patients with neurofibromatosis Type 1. J. Neurosurg. Pediatr., 11(4):410-6, 2013.

DeBella, K.; Szudek, J. \& Friedman, J. M. Use of the national institutes of health criteria for diagnosis of neurofibromatosis 1 in children. Pediatrics, 105(3 Pt. 1):608-14, 2000.

Ergün, S. S.; Atilganoglu, U. \& Yasar, H. Ear deformity due to neurofibromatosis type 1. Aesthetic Plast. Surg., 31(4):403-5, 2007.

Gutmann, D. H.; Aylsworth, A.; Carey, J. C.; Korf, B.; Marks, J.; Pyeritz, R. E.; Rubenstein, A. \& Viskochil, D. The diagnostic evaluation and multidisciplinary management of neurofibromatosis 1 and neurofibromatosis 2. JAMA, 278(1):51-
7, 1997.

Janes, L. E.; Sabino, J.; Matthews, J. A.; Papadimitriou, J. C.; Strome, S. E. \& Singh, D. P. Surgical management of craniofacial neurofibromatosis type 1 associated tumors. J. Craniofac. Surg., 24(4):1273-7, 2013.

Jouhilahti, E. M.; Peltonen, S.; Heape, A. M. \& Peltonen, J. The pathoetiology of neurofibromatosis 1. Am. J. Pathol., 178(5):1932-9, 2011

Karwacki, M. W. \& Wozniak, W. The Skeleton Abnormalities in Patients with Neurofibromatosis Type 1: Important Consequences of Abnormal Gene Function. In: Dionyssiotis, Y. (Ed.). Osteoporosis. New York, InTech, 2012. pp.323-41.

Kissil, J. L.; Blakeley, J. O.; Ferner, R. E.; Huson, S. M.; Kalamarides, M.; Mautner, V. F.; McCormick, F.; Morrison, H.; Packer, R.; Ramesh, V.; Ratner, N.; Rauen, K. A.; Stevenson, D. A.; Hunter-Schaedle, K. \& North, K. What's new in neurofibromatosis? Proceedings from the 2009 NF Conference: new frontiers. Am. J. Med. Genet. A, 152A(2):269-83, 2010.

Korf, B. R. Neurofibromatosis. Handb. Clin. Neurol., 111:333-40, 2013.

Latham, K.; Buchanan, E. P.; Suver, D. \& Gruss, J. S. Neurofibromatosis of the head and neck: classification and surgical management. Plast. Reconstr. Surg., 135(3):845-55, 2015.

Marchetti, M.; Franzini, A.; Nazzi, V.; De Martin, E. \& Fariselli, L. Radiosurgical treatment of ulnar plexiform neurofibroma in a neurofibromatosis type 1 (NF1) patient. Acta Neurochir. (Wien), 155(3):553-5, 2013.

Raj, A.; Baidya, K.; Ghosh, S.; Mondal, L.; Bhaduri, G. \& Sadhu, A. Neurofibromatosis I. Ophthalmology, 116(3):598-598.e1, 2009.

Sehgal, V. N.; Oberai, R.; Venkatash, P.; Sharma, S.; Verma, P. \& Chatterji, K. Plexiform neurofibroma affecting the upper parietal scalp, with cerebellar hamartoma: role of histopathology, colour Doppler imaging and magnetic resonance imaging. Clin. Exp. Dermatol., 38(3):285-8, 2013.

Sehgal, V. N.; Sharma, S. \& Oberai, R. Evaluation of plexiform neurofibroma in neurofibromatosis type 1 in 18 family members of 3 generations: ultrasonography and magnetic resonance imaging a diagnostic supplement. Int. J. Dermatol., 48(3):275-9, 2009.

Shen, X. Q.; Shen, H.; Wu, S. C.; Lv, Y.; Lu, H. \& Lin, X. J. Surgically treated solitary giant gluteal and retroperitoneal neurofibroma: a case report. World $J$. Surg. Oncol., 14:125, 2016.

Theos, A.; Korf, B. R.; American College of Physicians \& American Physiological Society. Pathophysiology of neurofibromatosis type 1. Ann. Intern. Med., 144(11):842-9, 2006.

van Zuuren, E. J. \& Posma, A. N. Diffuse neurofibroma on the lower back. J. Am. Acad. Dermatol., 48(6):938-40, 2003.

Weiss, B.; Widemann, B. C.; Wolters, P.; Dombi, E.; Vinks, A.; Cantor, A.; Perentesis, J.; Schorry, E.; Ullrich, N.; Gutmann, D. H.; Tonsgard, J.; Viskochil, D.; Korf, B.; Packer, R. J. \& Fisher, M. J. Sirolimus for progressive neurofibromatosis type 1-associated plexiform neurofibromas: a neurofibromatosis Clinical Trials Consortium phase II study. Neuro Oncol., 17(4):596-603, 2015.

Yoo, K. H.; Kim, B. J.; Rho, Y. K.; Lee, J. W.; Kim, Y. J.; Kim, M. N. \& Song, K. Y. A case of diffuse neurofibroma of the scalp. Ann. Dermatol., 21(1):46-8, 2009.

Yuan, S. M.; Cui, L.; Guo, Y.; Wang, J.; Hu, X. B.; Jiang, H. Q. \& Hong, Z. J. Surgical management of giant neurofibroma in soft tissue: a single-center retrospective analysis. Int. J. Clin. Exp. Med., 8(4):5245-53, 2015.

Zhang, X.; Mao, X.; Zhang, W.; Zhang, J. \& Cao, W. Giant head neurofibroma. Neurology, 78(1):71, 2012

Zhu, L.; Shi, L.; Wang, B.; Bi, M.; Pu, J.; Zhang, L.; Zhang, Y.; Wang, X. \& Zhang, G. Novel mutations in one allele in a Chinese family with neurofibromatosis type 1: Including a complex insertion-deletion mutation. J. Dermatol., 43(11):1332-5, 2016.

Boyd, K. P.; Korf, B. R. \& Theos, A. Neurofibromatosis type 1. J. Am. Acad. Dermatol., 61(1):1-14, 2009.

Holt, J. F. 1977 Edward B. D. Neuhauser lecture: neurofibromatosis in children. A. J. R. Am. J. Roentgenol., 130(4):615-39, 1978.

Correspondence author:

Lianbo Zhang

Department of Plastic Surgery

China-Japan Union Hospital of Jilin University

Changchun 130033

CHINA

Received: 26-09-2017

Accepted: 23-09-2017

E-mail: doctorzhanglianbo@163.com 